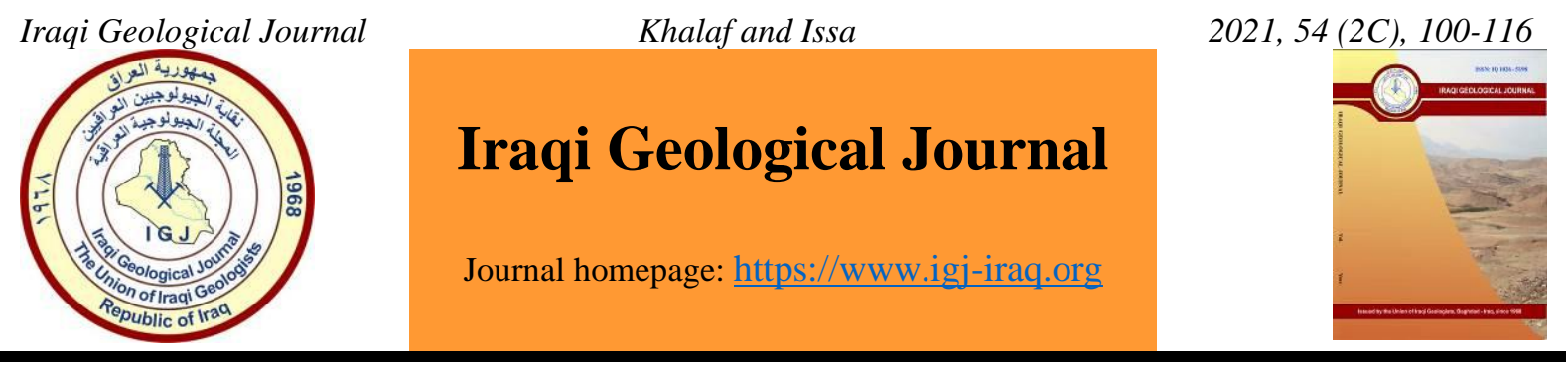

\title{
Determining the Physical and Chemical Properties of the Soils in Babylon and Al-Qadisiyyah for Manufacturing Clay Bricks
}

\author{
Muhsen O. Khalaf ${ }^{1, *}$ and Bilal M. A. Issa ${ }^{1}$ \\ 1 Department of Applied Geology, College of Science, University of Babylon, Babylon, Iraq \\ *Correspondence: bilal.is.1985@gmail.com
}

Received: 26 February 2021; Accepted: 10 May 2021; Published: 30 September 2021

\begin{abstract}
The research included conducting a study of eight selected soil Stations in the Babylon and Al Qadisiyyah. The main target of the research is to study the physical, chemical, and compressive strength properties of these soils and their suitability for manufacturing ordinary clay bricks. It was found through the evaluation of the soils of the studied samples that their physical properties ranged as follows: the water content (13.52-31.88\%) and the grain size analysis of the proportions of sand, silt, and clay as follows: (5-27\%) (38-48\%) (33-47\%), respectively. The values of the Atterberg limits ranged as follows: the plastic limit ratios (13-21\%), liquid limit (34-49\%), plasticity index (13-28\%), and the specific gravity ranged between (2.43-2.67). As for the chemical properties of the studied samples, they consist of a lot of silicates, carbonate calcium, and calcium oxide. Studied samples were characterized by water absorption $15-24 \%$, and the efflorescence is varied from medium, low to nil. The soil samples are consequently considered as a suitable material for the manufacture of ordinary bricks in grades A and B based on Iraqi Standard specifications No. 25.
\end{abstract}

Keywords: Physical properties; Chemical properties; Clay bricks; Chemical analysis; Water

\section{Introduction}

The clay bricks industry is the oldest building material industry and still has the lead in most countries of the world, and Iraq is one of these countries that are famous in this industry for the abundance of raw materials in most of its regions, (Al-Duwaf, 1978; Awadh and Awad, 2021). Clay bricks are building bricks of regular dimensions $(24 \times 11.5 \times 7.5 \mathrm{~cm})$ according to Iraqi Standard specifications No. 24 (IQS, 1988), and they are easy to use, transport and manufacture, and can withstand heavy weights and resist impacts and weather changes. The primary material for manufacturing bricks is soil with volumetric gradations between clay, silt, and sand, and it ranges between (13-18\%) for sand, (42-46\%) for silt, and (41-42\%) for clay. Hawraa, (2019) and its work shall be in the form of dough after mixing it with water, cutting it, drying it, and burning it in special ovens. Increasing the proportion of clay leads to cracking of the bricks manufactured and an increase in the percentage of sand leads to a decrease in durability. And the soil must have certain plasticity after adding water to it. The plasticity depends on the ratio of clay minerals and the size and shape of the clay-forming particles (Norbury, 2016; Awadh and). The fineness of the granular size of clay, the lamellar form of clay particles, and the special relationship between clay particles and water helps the clay dough to gain

DOI: $\underline{10.46717 / i g j .54 .2 C .10 M s-2021-09-29}$ 
plasticity. (Nesse, 2000). The proportions of the chemical compounds that make up the soil are directly related to the reactions that occur during the burning and the metal phases formed (Bapeer, 2017). Also, the presence of salts in the soil prepared for manufacturing bricks hurts the manufactured bricks, and they are of two types depending on their solubility in water, they may be water-soluble salts and insoluble salts which are in the form of sulfates and chlorides mainly and residual salts. (Ajeet, 2015). Also, the dissolved salts in the formation water or with other additives may transfer to the bricks and remain on their surface after drying and the evaporation of the water where it remains after the crystallization process (during burning). This phenomenon is known as Efflorescence. Iraqi Standard specifications No. 24 (IQS,1988) specifies a description of Efflorescence and has a role in determining the class of bricks or they're unfit for use with a high degree (dense - very thick). Iraqi Standard specifications No. 25 (IQS, 1988). As for harmful substances that should be non-existent or have no significant effects, such as calcium carbonate, the increase of which leads to increasing the percentage of calcium carbonate leads to cracking and cracking of the bricks during the liberation of carbon dioxide and the disorganization of the free calcium oxide resulting from the calcium carbonate leads to cracking of the bricks, and it is preferable that the proportion of carbonates not exceed $40 \%$ in the clays used to manufacture the bricks, (Vodova et al., 2014). Also increasing the proportion of gypsum generates stresses during drying and leads to increased Efflorescence, high levels of swelling minerals such as montmorillonite lead to cracking of bricks during drying, and increasing the percentage of illite metal leads to cracking of the bricks during burning, (Camino et al., 2014).

\section{Location of the Study Area}

The location of the study area is in the Middle of Iraq, which is within the sedimentary plain, and this area are the governorates of Babylon and Qadisiyah, where they lie between longitude (E) Easting ( $43^{\circ} 55^{\prime} 2.31$ ", $\left.44^{\circ} 30^{\prime} 2.78 "\right)$ and latitudes (N) Northing ( $31^{\circ} 14^{\prime} 8.83,33^{\circ} 3^{\prime} 10.83$ "). The study area permeates the Euphrates River, where it enters the north of Babylon, and then branches into what to be known locally as (Shat Al Hilla). It also enters the Qadisiyah Governorate, where it is known locally (Shat Al Diwaniya), (Fig.1).

The study area is located to the south and southwest of the capital, Baghdad, where the center of Babylon Governorate is about $80 \mathrm{~km}$ from Baghdad, and the Qadisiyah Center is about $150 \mathrm{~km}$ from Baghdad, where the study area surrounds six Iraqi governorates, which are as follows: Baghdad, AlAnbar, Karbala, Najaf, Al-Muthanna, and Wasit, (Fig. 1). The surface of the region, in general, is characterized by its flatness, covered by topsoil, rich with plants roots, and its general slope from north to south, as it is clear that the equal elevation line $(65 \mathrm{~m})$ above sea level passes in its northern parts in the Babylon Governorate, while the equal elevation line $(10 \mathrm{~m})$ above Sea level passes through its southern parts in the Qadisiyah (Fig.2).

\section{Climate of the study Area}

The climate of Iraq is generally described as dry, hot summer, and cold, rainy winter, with fluctuations in temperature from day to night, limited rainfall, and varying degrees of precipitation more than $1000 \mathrm{~mm}$ in the north to less than $100 \mathrm{~mm}$ in the south, (Al-Garawi, 2020) and (Al-Dabbas et al., 2012).The climate controls the dispersion and distribution of vegetation and the abundance of water resources, including physical and chemical properties, as well as it has an impact on soil formation and sediments, and the transfer of these sediments as a result of erosion processes. The heat and rainfall factors are the most factors influencing the climate of the study area, as the temperature is hot, dry, and relatively high in summer, between 19-43.6 $\mathrm{C}^{\circ}$. The climate is mild, humid with high evaporation and rain limited to winter with relatively between $0-70.7 \mathrm{~mm}$. low temperatures between 5.9-27.5. The period of rainfall in Iraq is limited to eight months of the year, as it generally begins at the end of the 
first half of October and ends at the end of the second half of May, and in small quantities during October, which is the first month of the autumn season. Thus, evaporation is one of the main climatic factors that determine the amount of rain, as it is affected by heat and wind factors. When temperatures rise, the rate of evaporation raises, and consequently, the soil moisture decreases, and in turn, the concentration of salts in it increases, (Khalaf, 2019), Fig. 2 shows the relationship between monthly rainfall totals values $(\mathrm{mm})$ and monthly evaporation totals values $(\mathrm{mm})$ for the study area for the year 2020 from the Iraqi Meteorological and Seismic Monitoring Authority.

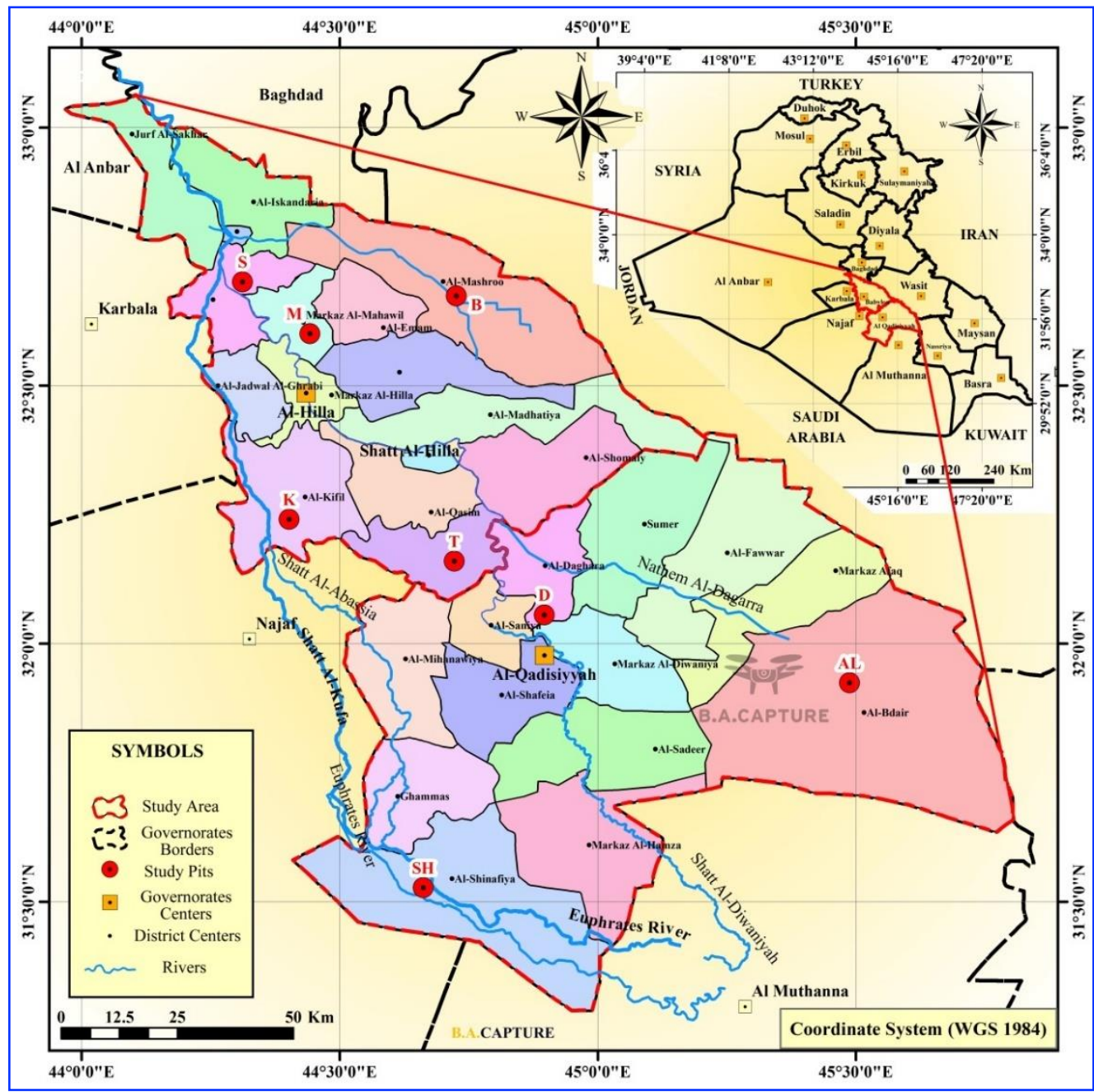

Fig. 1. Map of the study area showing the stations, by (Capture,2021).

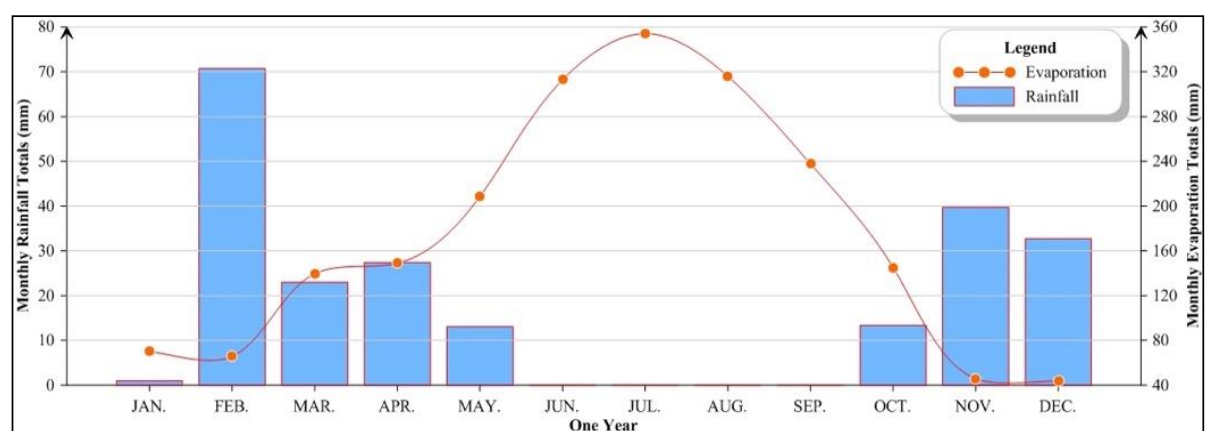

Fig. 2. The relationship between monthly totals values for rainfall and evaporation $(\mathrm{mm})$ in the study area 


\section{Geology and Topography of the Study Area}

In general, the geology of the study area is not different from the geology of the sedimentary plain because it is located within it, where the sediments that cover the study area return to the era in which the rivers formed, which is the Quaternary area. Exposure to a series of periodic precipitation and weather conditions as a result of climate changes during the Ice Age is what distinguishes this sedimentary plain. The largest part of the research area from the geological point of view is covered by (Flood Plain Deposits). The northeast, eastern and southeastern part of the study area is generally covered with Aeolian Deposits. Study area is characterized by Depression fill deposit, Dry marsh deposit, and Inland sabkha deposit.

The surface of the study area, in general, is characterized by its flatness and its general slope from north to south, as it is clear from Fig. 3 that the equal elevation line $(65 \mathrm{~m})$ above sea level passes in its northern parts in Babylon Governorate, while the equal elevation line $(10 \mathrm{~m})$ above Sea level passes through its southern parts in the Qadisiyah Governorate. Despite this general flatness of the surface, it is not without some slight local terrain that the average height between them does not exceed about two meters per every $(100 \mathrm{~m})$ extension. This is evident in the difference between the elevations in the vicinity of the rivers and the areas far from them, as strips extend from relatively high areas along the course of the Euphrates and its two main branches.

\section{Materials and Methods}

In this section, we address the methods used to accomplish this research, where laboratories, devices, and techniques were used to complete the required laboratory tests and chemical analyzes so that we can understand the most accurate results for the clays of the study area that include several stages starting from the survey stage in the process of collecting information related to geology in the study area available on mud. In addition to preparing geological and site maps for the eight stations and starting with the detailed fieldwork stage which consists of collecting, transferring, and preparing samples for physical, chemical, engineering, and mineral examinations, and with a statement its suitability for manufacturing bricks and comparing all its properties with the Iraqi specifications for bricks.

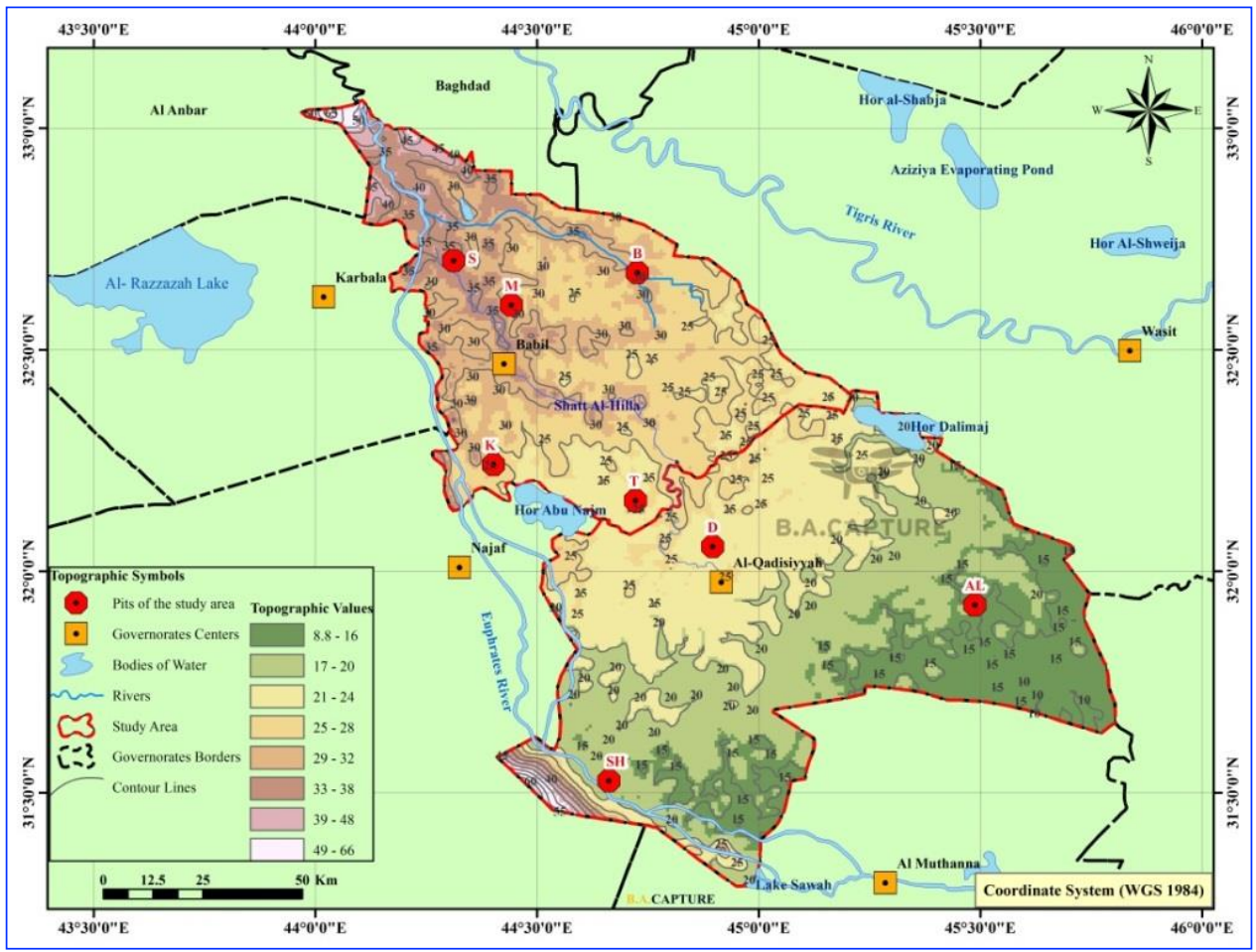

Fig. 3. Topographic map of the study area showing the stations. (Capture, 2021). 
The study was carried out by conducting fieldwork and laboratory tests for clay soils as raw material, laboratory preparation for bricks, and laboratory tests to evaluate the manufactured bricks, all of which was accomplished as follows:

The physical and chemical analysis of the soil and the physical tests (grain size and atterberg limits) of the manufactured bricks were all carried out in the laboratories of the Department of Applied Geoscience in the Faculty of Sciences of the University of Babylon. The process of manufacturing laboratory brick samples was performed in the construction materials laboratories of the Faculty of Materials Engineering at the University of Babylon in an extrusion method using the Injection device which is national manufacture that works on electrical energy and contains a hydraulic piston and an extrusion tube and mixer to mix the soil sample. The process of drying and burning the bricks of the manufactured products took place in the Hawraa Babylon Bricks Factory located in the Al-Mahawil area in Babylon Governorate. The compressive strength test for the bricks was carried out at the National Center for Construction Laboratories, Laboratory of Babylon.

\section{Field Work}

\subsection{Selecting Studied Areas}

Field detection was conducted to select suitable stations for drilling and study the surrounding areas ecologically and their expanse from agricultural lands and irrigation tasks and the extent of the comfort of access to them, etc. Where the coordinates were recorded using GPS as shown in Table 1.

Table 1. Codes and coordinates system of the study area stations

\begin{tabular}{cccc}
\hline Pits code & Site of stations & \multicolumn{2}{c}{ The coordinates } \\
\hline & & Longitude (E) & Latitude (N) \\
M & Quarry of Al-Mahawil Brick Factory & $44^{\circ} 26^{\prime} 31.36^{\prime \prime}$ & $32^{\circ} 36^{\prime} 5.547^{\prime \prime}$ \\
B & Al-Mashroo district- Babylon & $44^{\circ} 43^{\prime} 33.529^{\prime \prime}$ & $32^{\circ} 40^{\prime} 23.692^{\prime \prime}$ \\
S & Al-Hindiya district- Babylon & $44^{\circ} 18^{\prime} 42.953^{\prime \prime}$ & $32^{\circ} 42^{\prime} 1.537^{\prime \prime}$ \\
K & Al-Kifil district- Babylon & $44^{\circ} 24^{\prime} 5.634^{\prime \prime}$ & $32^{\circ} 14^{\prime} 30.662^{\prime \prime}$ \\
T & Al-Taliaa district- Babylon & $44^{\circ} 43^{\prime} 16.874^{\prime \prime}$ & $32^{\circ} 9^{\prime} 37.127^{\prime \prime}$ \\
D & Quarry of Al- Al Qadisiyyah Brick & $44^{\circ} 53^{\prime} 47.662^{\prime \prime}$ & $32^{\circ} 3^{\prime} 22.402^{\prime \prime}$ \\
AL & Factory & $45^{\circ} 29^{\prime} 15.271^{\prime \prime}$ & $31^{\circ} 55^{\prime} 29.831^{\prime \prime}$ \\
SH & Al-Bdair district- Al Qadisiyyah & $44^{\circ} 39^{\prime} 42.448^{\prime \prime}$ & $31^{\circ} 31^{\prime} 37.546^{\prime \prime}$ \\
\hline
\end{tabular}

\subsection{Drilling Work}

The drilling process was done on 7, April 2019, the climate was dry and all the study stations using a hand drill tool (Auger). This tool penetrates the soil to make a hole with a diameter of 4 inches and contains four iron connections, each with a length of 1 meter and thus the depth of the pit is 4 meters which is presented in Fig. 4.

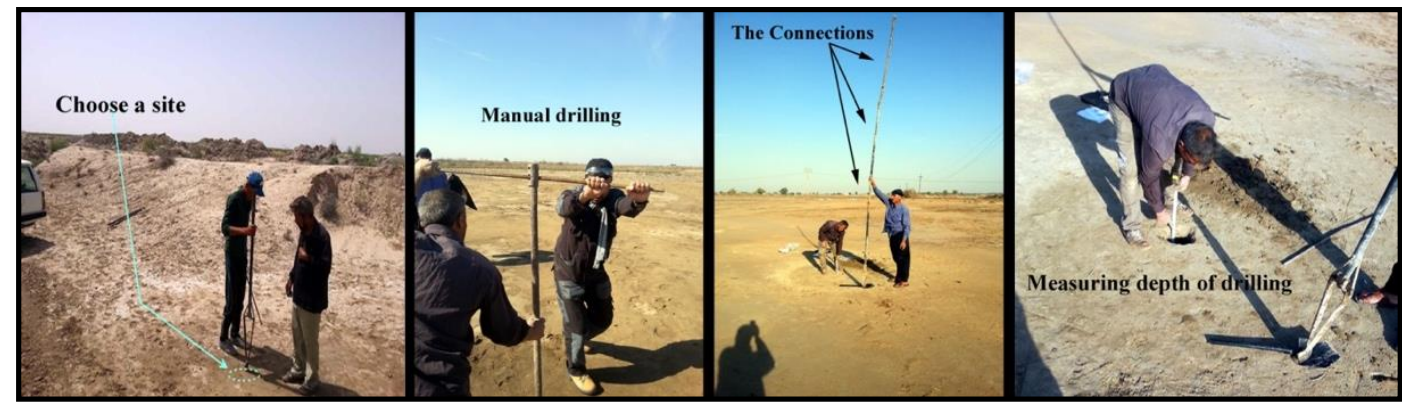

Fig.4. The tool used for drilling pits (Auger) 


\subsection{Description of the Soil}

Description of the soil through continuous field inspection by theoretical and manual examination for every half a meter of pits and calculating the groundwater level for the selected stations depending on the station suitability for manufacturing bricks. The studied soil was also described after conducting geotechnical examinations on it using the Unified Soil Classification System (ASTM D-2486, 2017).

\subsection{Groundwater Level}

The groundwater level measurement process was carried out after the drilling process and the samples were extracted, where the level was measured 24 hours after the drilling process, where the level of the groundwater depth in the studied areas ranged between 2 and 3.5 meters, therefore, samples water content $\%$ values are high.

\subsection{Sampling Stage}

Sampling was performed on all eight pits at the rate of extraction of one sample per half a meter, (8) samples per hole from half a meter to four meters, for the last sample, and these eight samples were mixed to create one mixture per hole with a depth of 4 meters. Full, where the samples were taken and placed in pre-numbered sampling bags and tightly linked to preventing contamination or loss of moisture or the like, to conduct laboratory tests on it and manufacturing samples of laboratory bricks from the same soil (raw material) and then conducting physical evaluation tests on these samples, and then comparing them with Iraqi Standard specifications No. (25) (IQS,1988) to manufacture clay bricks and Item identification.

\subsection{Laboratory Work}

The laboratory examination was conducted on the samples collected from the pits, where the eight samples were mixed for each pit separately and a mixed sample was created for these pits, which means (Mix-M, Mix-D, Mix-T, Mix-B, Mix-AL, Mix-SH, Mix-K, and Mix-S) Where the tests according to A.S.T.M., and IQS included the following:

1- Physical tests.

- Water content test.

- Grain size analysis test.

- Specific gravity test.

- Absorption test.

2- Chemical Analysis, USDA60.

- Calculate the proportions of each of the following oxides: $\mathrm{SiO}_{2}, \mathrm{CaCO}_{3}, \mathrm{CaO}, \mathrm{Fe}_{2} \mathrm{O}_{3}, \mathrm{Al}_{2} \mathrm{O}_{3}$, $\mathrm{MgO}, \mathrm{SO}_{3}, \mathrm{Na}_{2} \mathrm{O}$, and $\mathrm{K}_{2} \mathrm{O}$.

3- Engineering Test.

- Compressive Strength.

\section{Results and Discussion}

\subsection{Physical Test}

\subsubsection{Water content test}

It is a ratio of the weight of water to the weight of solids in the soil mass and expresses the water content by a percentage and its values may range between zero and may exceed $100 \%$ when the weight 
of the water in the soil is more than the weight of the solid (Al-Waeli, 2018, Bapeer, 2017 and Awadh and Awad, 2021).

The examination was performed on 8 samples of field mixed samples obtained from drilling the study area, according to the American standard (ASTM-D4959, 2007).The purpose of this examination is to find the water content of soil samples(ASTM-D2216, 2010), where the water content of the soil is used to give an idea of the soil consistency and degree of saturation with water and its durability, (Table 2), as it is involved in many engineering calculations related to soil mechanics issues, (Younas, 2017).

Table 2. Water content evaluation of the mixtures of the study pits

\begin{tabular}{lc}
\hline Sample code & Water content \% \\
\hline Mix-M & 20.52 \\
Mix-D & 24.15 \\
Mix-T & 28.03 \\
Mix-B & 25.59 \\
Mix-AL & 24.40 \\
Mix-SH & 28.44 \\
Mix-K & 29.76 \\
Mix-S & 31.88 \\
Range & $\mathbf{1 3 . 5 2 - 3 1 . 8 8}$ \\
Average & $\mathbf{2 5 . 1 2}$ \\
\hline
\end{tabular}

\subsubsection{Grain size analysis test}

Volumetric examination of clay, silt, and sand parts using a sieve and wet analysis with $152 \mathrm{H}$ hydrometer. The grain size analysis is the distribution of granules depending on their size. Before proceeding to dry sieve analysis, the soil with all its components is washed on a 75-micron sieve (No. 200) to separate coarse grains (sand) from fine grains (silt and clay). This method determines for us the exact amount of coarse and fine soil components, as the method used in this specification depends on American Standard (ASTM-D422, 2017) on the use of water or dispersed to separate and remove microscopic materials from the 75-micron sieve (No. 200) where 8 samples were separated to the clays of the study area, also during this process, soluble materials such as salts and other minerals can be removed, (Ajeet, 2015); (Awad and Awadh, 2020). Practical experience has proven over time that to obtain bricks of good quality and subject to specifications, the dough prepared for the brick industry must be with specific proportions of size gradients between clay, sand, and silt. Increasing the clay leads to cracking of the bricks and an increase in sand leads to a decrease in durability. Work experiences showed that the best grades for Manufacturing class (A) and class (B) bricks are as shown in Table 3 (Hawraa, 2019).

Table 3. The best gradient for manufacturing class A and B bricks, (Hawraa, 2019).

\begin{tabular}{ccc}
\hline The size & \multicolumn{2}{c}{ Brick Class } \\
\hline & Class A & Class B \\
Sand & $13-18 \%$ & $19-23 \%$ \\
Silt & $42-46 \%$ & $39-41 \%$ \\
Clay & $41-42 \%$ & $41-43 \%$ \\
\hline
\end{tabular}

Wet analysis using a hydrometer was performed according to American Standard (ASTM D-422, 2017), the percentage of clay, silt, and sand parts are shown according to Table 4 and Figs. 5,6\&7. 
Table 4. The percentage of sand, silt, and clay portions of the mixtures of the study area.

\begin{tabular}{cccc}
\hline Sample code & Sand \% & Silt \% & Clay \% \\
\hline Mix-M & 20 & 39 & 41 \\
Mix-D & 15 & 45 & 40 \\
Mix-T & 21 & 38 & 41 \\
Mix-B & 13 & 46 & 41 \\
Mix-AL & 5 & 48 & 47 \\
Mix-SH & 27 & 40 & 33 \\
Mix-K & 15 & 43 & 42 \\
Mix-S & 6 & 47 & 47 \\
Range & $5-27$ & $38-48$ & $33-47$ \\
Average & 15 & 43 & 42 \\
\hline
\end{tabular}

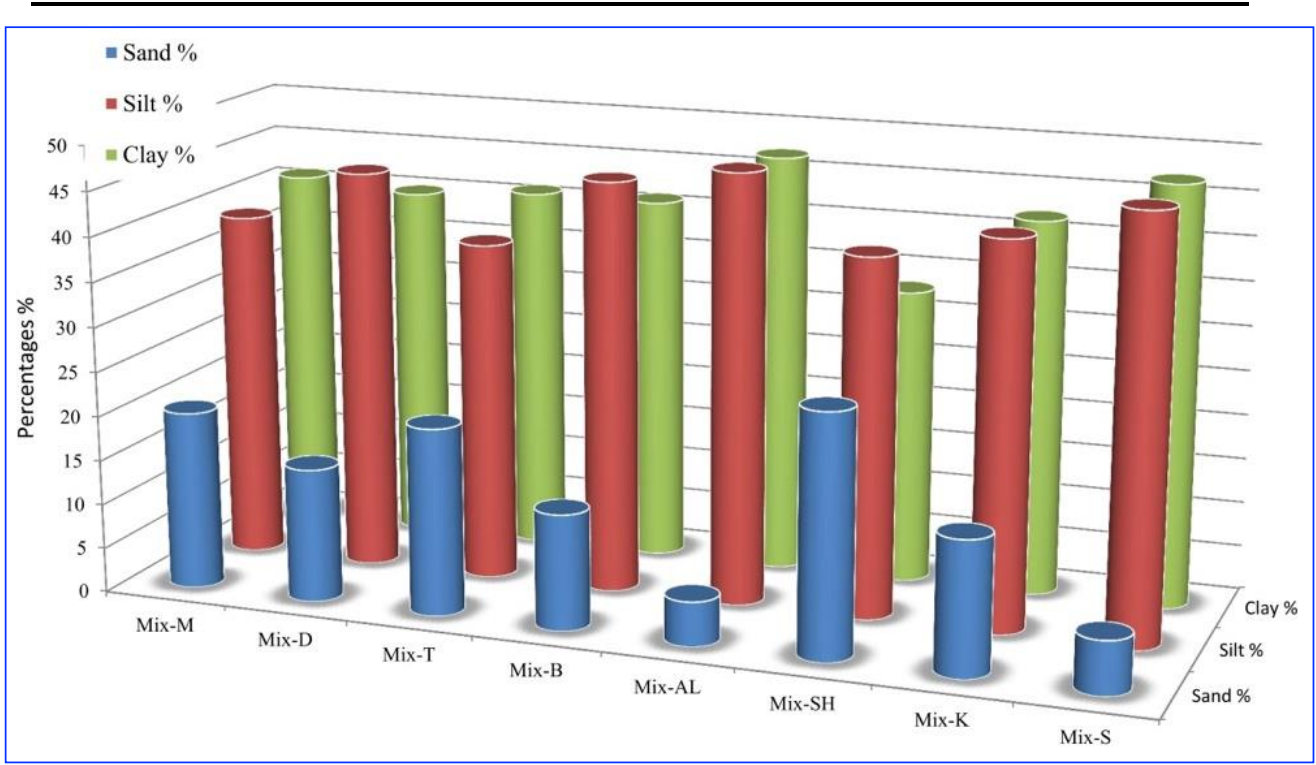

Fig.5. The sketch showing the percentages of sand, silt, and clay for mixtures of the study area

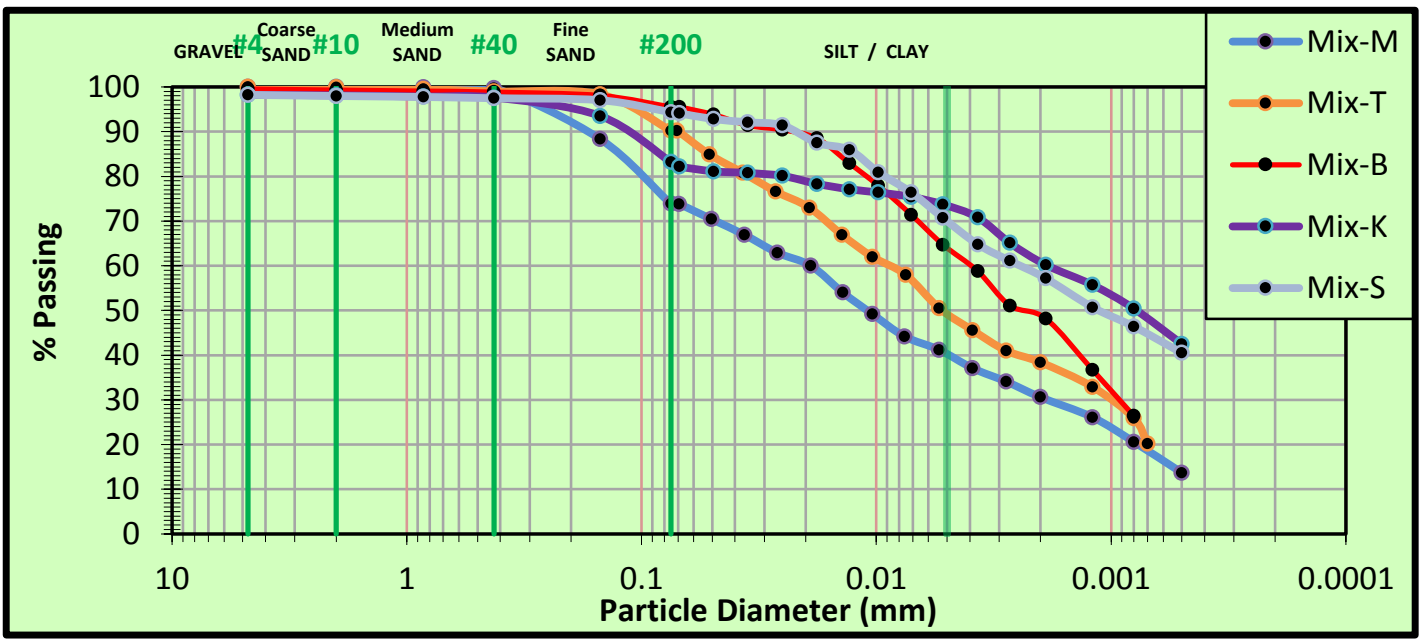

Fig .6. Grain size distribution curve for the soil of pits in Babylon 


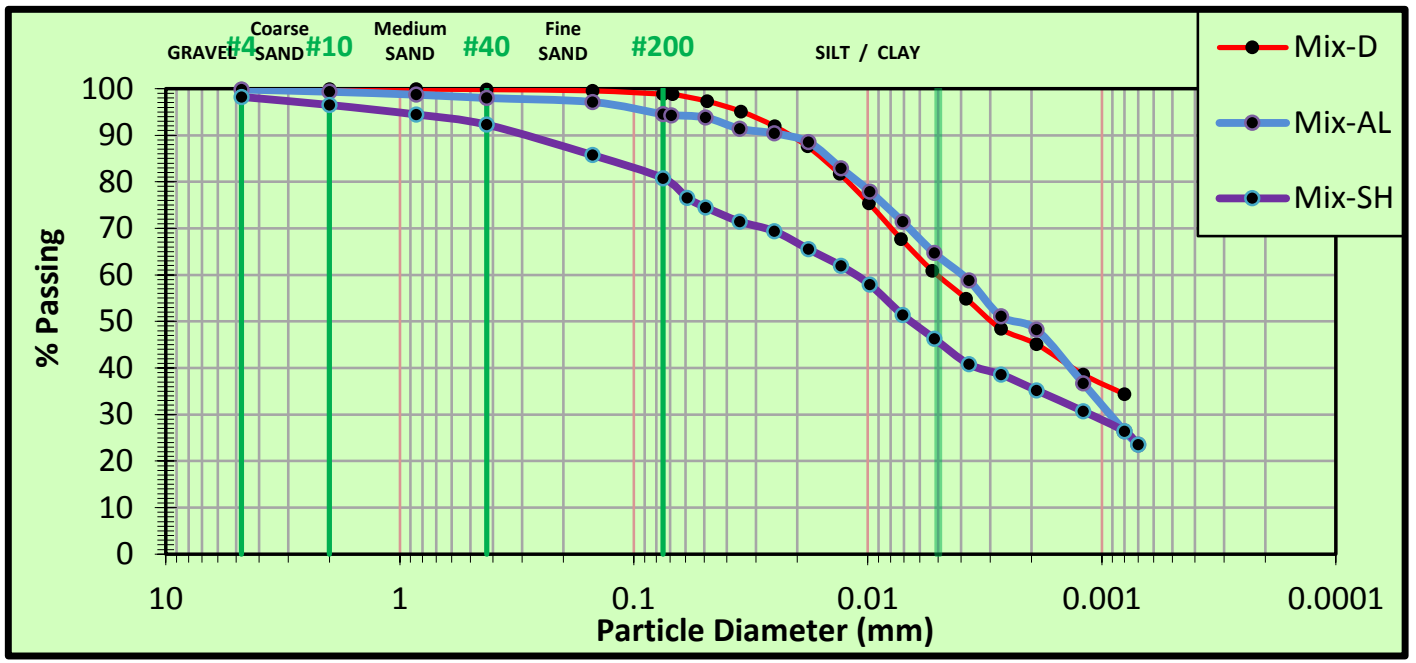

Fig .7. Grain size distribution curve for the soil of pits in Al-Al Qadisiyyah

In the study area, in general, the properties of soil components vary, such as sand, silt, and clay, as they are, unsuitable for the manufactured of clay bricks due to the salinity of some areas, but the pits selected in the study area and according to the grain size analysis showed good and suitable properties for the manufacture of clay bricks by comparing the values of the grain size distribution of the studied station's samples with (Table 3).

\subsubsection{Atterberg limits test}

The Atterberg limits which include; plastic limit (P.L\%), liquid limit (L.L\%), and plasticity index (P.I\%), were calculated to the eight samples of soil mixtures of the study area, (Table 5) according to the American standard (ASTM D4318, 2010) depending on the plasticity chart (Fig. 8) using the (Gassagrandi) device which is a copper vessel that can be electrically moved and its number recorded by a meter attached to the device.

Table 5. Values are derived for the Atterberg limits from the soil of the study area, (L.L, P.L, P.I)

\begin{tabular}{lcccc}
\hline Sample code & L.L\% & P.L\% & P.I\% & USCS class \\
\hline Mix-M & 40 & 17 & 23 & CL \\
Mix-D & 43 & 20 & 23 & CL \\
Mix-T & 45 & 19 & 26 & CL \\
Mix-B & 36 & 13 & 23 & CL \\
Mix-AL & 41 & 21 & 20 & CL \\
Mix-SH & 34 & 21 & 13 & CL \\
Mix-K & 39 & 19 & 20 & CL \\
Mix-S & 49 & 21 & 28 & CL \\
Range & $34-49$ & $13-21$ & $13-28$ & \\
Average & 41 & 19 & 22 & \\
\hline
\end{tabular}

Atterberg limits are affected by the amount and nature of the clay minerals content in the soil, where plasticity is an important factor in determining the operability of clays or clay mixtures and their application for construction industries such as bricks, ceramics, and pottery, and it is also a good indicator of the phases of the main clay minerals in the soil, (Yongue et al., 2016). In comparison with the research and studies that have been conducted, the range in which the plasticity ratios of the studied soils appeared is suitable for the manufacture of clay bricks and with different varieties depending on the rest of the components. 


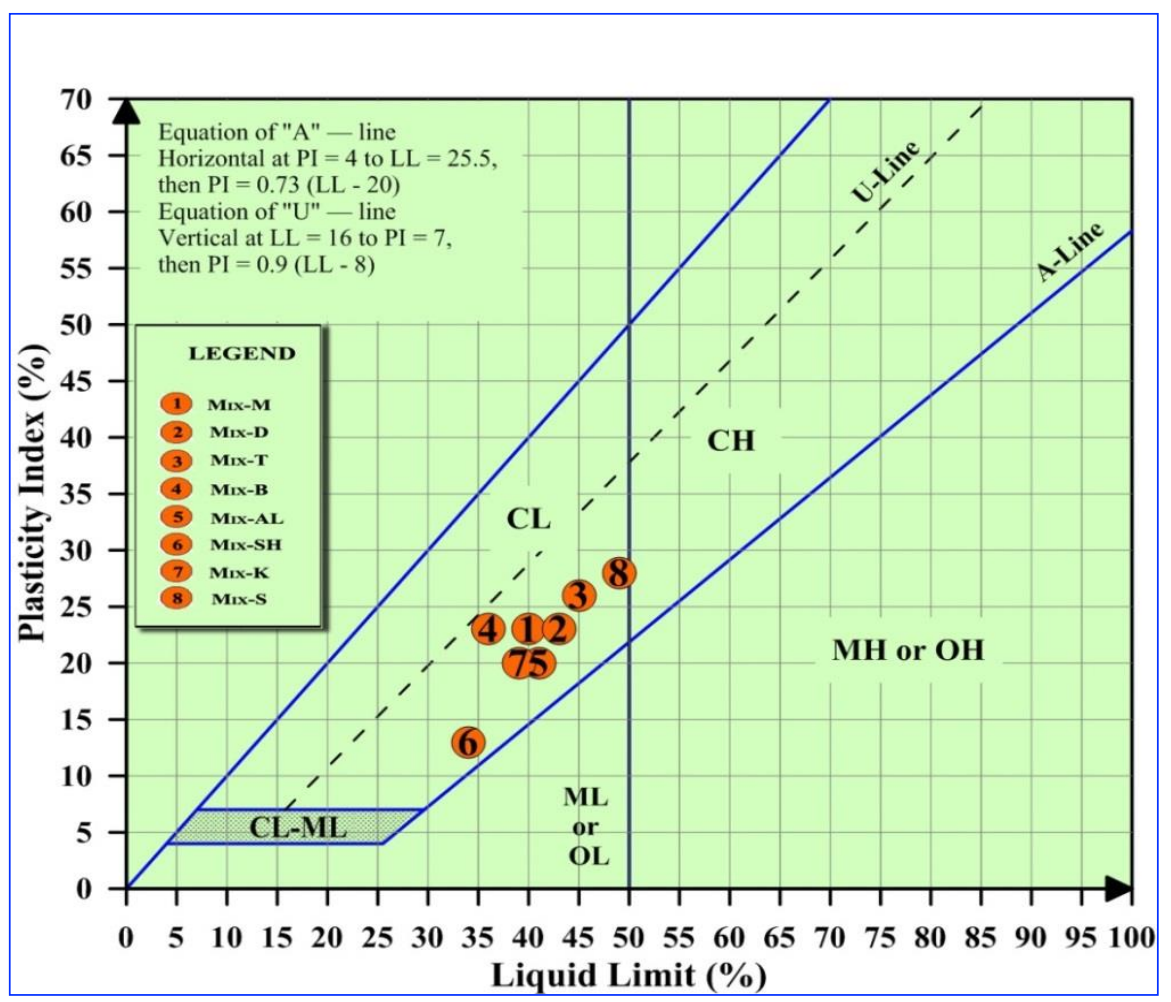

Fig.8. The plasticity chart shows the results of the soil stations.

\subsubsection{Specific gravity test}

Specific gravity represents the ratio between the weight of a given volume of solids to the weight of the same volume of water and is usually unit-free, (Younas, 2017). The specific gravity of the eight sample mixtures from the study pits was measured and represents the drilling mixtures completely from the surface till 4 meters(Table 6), according to (ASTM D854-10) was approved in this examination and was examined in the laboratories of the General Authority for the Geological Survey and Iraqi MiningBaghdad.

Table 6. Values of the specific gravity of the soil mixes of the study pits

\begin{tabular}{lc}
\hline Sample code & Specific gravity \\
\hline Mix-M & 2.66 \\
Mix-D & 2.59 \\
Mix-T & 2.67 \\
Mix-B & 2.54 \\
Mix-AL & 2.43 \\
Mix-SH & 2.60 \\
Mix-K & 2.49 \\
Mix-S & 2.60 \\
Range & $2.43-2.67$ \\
Average & 2.57 \\
\hline
\end{tabular}

\subsection{Chemical Analysis}

The ratios of chemical compounds are directly related to the reactions that occur during the burning and the metal phases that are formed. 
Chemical analysis was conducted on the eight samples mixed from the drilling of the study area to find out the properties of oxides present in the mixtures of these soils by using volumetric gravimetric methods, whereby (14) examinations of the properties of oxides were performed according to the following specifications:

- Handbook No. 60., (1990)

- ASTM C114-04 (2004)

- (B.S.) 1377: 3 (1988)

- ASTM D7348 (2008) L.O.I.

The results obtained are shown in Table 7 and Fig.9.

Table 7. Chemical examination results from the soil of the study area

\begin{tabular}{|c|c|c|c|c|c|c|c|}
\hline \multicolumn{8}{|c|}{ Part One } \\
\hline No. & $\mathrm{SiO}_{2}$ & $\mathrm{CaCO}_{3}$ & L.O. I & $\mathrm{CaO}$ & $\mathrm{Fe}_{2} \mathrm{O}_{3}$ & $\mathrm{Al}_{2} \mathrm{O}_{3}$ & MgO \\
\hline Mix-M & 54.59 & 29.30 & 12.33 & 9.04 & 6.22 & 3.01 & 3.65 \\
\hline Mix-D & 52.26 & 31.00 & 20.32 & 11.42 & 6.08 & 3.62 & 3.70 \\
\hline Mix-T & 53.10 & 32.70 & 17.55 & 11.92 & 6.29 & 3.96 & 3.49 \\
\hline Mix-B & 50.95 & 35.20 & 18.30 & 12.15 & 6.36 & 3.79 & 3.61 \\
\hline Mix-AL & 50.36 & 37.10 & 19.04 & 13.86 & 5.36 & 3.65 & 3.78 \\
\hline Mix-SH & 47.81 & 36.60 & 19.57 & 14.85 & 4.20 & 3.17 & 3.42 \\
\hline Mix-K & 55.44 & 29.40 & 16.93 & 11.18 & 6.44 & 3.67 & 3.19 \\
\hline Mix-S & 56.41 & 31.00 & 16.24 & 11.93 & 5.92 & 2.59 & 3.74 \\
\hline Range & $47.81-56.41$ & 29.3-37.1 & $12.33-20.32$ & $9.04-14.85$ & $4.20-6.44$ & $2.59-3.96$ & $3.19-3.78$ \\
\hline Average & 52.62 & 32.79 & 17.54 & 12.04 & 5.86 & 3.43 & 3.57 \\
\hline \multicolumn{8}{|c|}{ Part Two } \\
\hline No. & T.S.S. & Gypsum & $\mathrm{SO}_{3}$ & $\mathrm{Na}_{2} \mathrm{O}$ & $\mathbf{K}_{2} \mathbf{O}$ & $\mathrm{Cl}^{-}$ & O.M. \\
\hline Mix-M & 2.78 & 0.58 & 0.27 & 1.24 & 0.85 & 0.15 & 0.43 \\
\hline Mix-D & 2.54 & 1.05 & 0.49 & 1.56 & 0.85 & 0.84 & 0.49 \\
\hline Mix-T & 2.74 & 5.27 & 2.45 & 1.36 & 0.84 & 0.10 & 0.47 \\
\hline Mix-B & 1.95 & 1.03 & 0.48 & 0.98 & 0.89 & 0.06 & 0.51 \\
\hline Mix-AL & 1.61 & 0.86 & 0.40 & 1.38 & 0.82 & 0.38 & 0.27 \\
\hline Mix-SH & 3.20 & 4.45 & 2.07 & 1.14 & 0.81 & 0.37 & 0.52 \\
\hline Mix-K & 1.21 & 0.80 & 0.37 & 1.30 & 0.88 & 0.16 & 0.20 \\
\hline Mix-S & 1.82 & 2.02 & 0.94 & 1.41 & 0.81 & 0.24 & 0.27 \\
\hline Range & $1.21-3.20$ & $0.58-5.27$ & $0.27-2.45$ & $0.98-1.56$ & $0.81-0.89$ & $0.06-0.84$ & $0.20-0.52$ \\
\hline Average & 2.23 & 2.01 & 0.93 & 1.30 & 0.84 & 0.29 & 0.39 \\
\hline
\end{tabular}

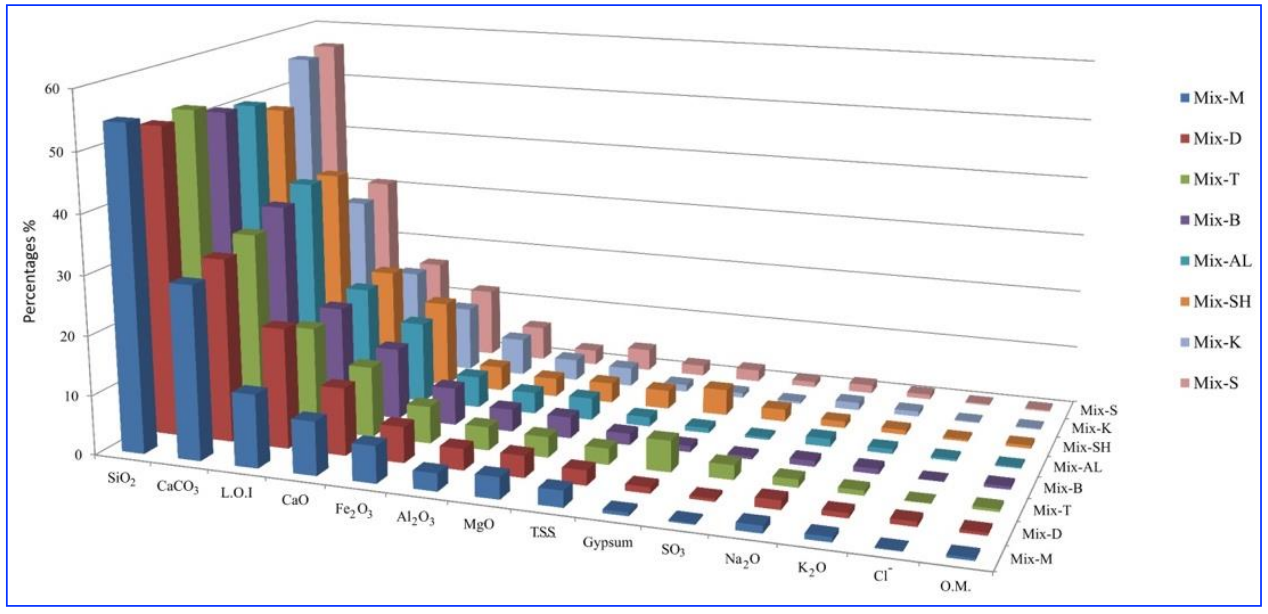

Fig .9. A chart showing the results of the chemical examination of the soil of the study area. 
Through the first observation of this chart, we notice that the properties of silicon oxide $\left(\mathrm{SiO}_{2}\right)$ are the highest among the rest of the ratios and this corresponds to the nature of sedimentary plain sediments, where it ranged between $47.81-56.41 \%$ and a rate of $52 \% 62$. Silica represents the highest percentage in clay samples as it is included in the crystal structure of clay minerals, especially in the tetrahedral plates and within the chemical composition of feldspar as well as free silica in the form of quartz mineral. Then comes the calcium carbonate percentage $\left(\mathrm{CaCO}_{3}\right)$, which ranged between 29.30$37.10 \%$ and a rate of $32.79 \%$. We find that the highest value was found in pits Mix-K, Mix-S in the district of Al-Kifl and Sada Al-Hindiya and the lowest value was in pit (Mix-SH) In Al-Shenafiya subdistrict in Al-Qadisiyah governorate.

The percentage of loss on ignition L.O.I ranged between $12.33-20.32 \%$ and a rate (17.54\%). The percentage of L.O.I depends on the purity of the raw materials, and it results from the loss of water weight. When heating samples. If the value of L.O.I is lower, then this is due to the pollutants present in the soil, especially if the quartz content is high (Hussin et al., 2018). After that comes the properties of calcium oxide $(\mathrm{CaO})$, whose rate ranged between $9.04-14.85 \%$ and a rate of $(12.04 \%)$, where a positive correlation is observed with the percentage of L.O.I which reflects the presence of the mineral calcite, then comes the ferric oxide $\left(\mathrm{Fe}_{2} \mathrm{O}_{3}\right)$ ratios, which ranged between $4.220-6.44 \%$ and the rate $(5.86 \%)$ is associated with a positive relationship with calcium oxide $(\mathrm{CaO})$ and L.O.I. The effect of this oxide on the color of the burned samples from the laboratory brick samples and on the temperature at which the burning takes place. Then the proportions of aluminum oxide $\left(\mathrm{Al}_{2} \mathrm{O}_{3}\right)$, which ranged between 2.59-3.96\% and a rate of 3.43 has a positive relationship with $\mathrm{Fe}_{2} \mathrm{O}_{3}, \mathrm{MgO}$, and $\mathrm{K}_{2} \mathrm{O}$, which are oxides likely to be present in clay minerals (Illite, Chlorite, and Montmorillonite). The ratios of magnesium oxide $(\mathrm{MgO})$, which ranged between $3.19-3.78 \%$ and a rate of $3.57 \%$ is characterized by a positive correlation with aluminum oxide and iron, which is likely to be from the clay minerals (chlorite and palygorskite). The relationship A positive correlation with calcium oxide as a result of its presence in the mineral dolomite, we find that the values are somewhat close to each other for this oxide in all pits, after it the percentages of total dissolved salts (T.S.S.), which ranged between 1.21-3.20\% and at a rate of $2.23 \%$. After that, the percentages of gypsum ranged between $0.58-5.27 \%$ and a rate of $2.01 \%$ as we infer the presence of the mineral from chemical analyzes. Vase mixed with soil or in the form of scattered veins. The proportions of sulfur oxide $\left(\mathrm{SO}_{3}\right)$ ranged between $0.27-2.45 \%$ with a rate of 0.93 after that came the proportions of sodium oxide $\left(\mathrm{Na}_{2} \mathrm{O}\right)$, which ranged between $0.98-1.56 \%$ and a rate of $1.30 \%$, followed by the percentage of potassium oxide $\left(\mathrm{K}_{2} \mathrm{O}\right)$, which ranged between $0.81-0.89 \%$ with a rate of $0.84 \%$ then the percentage of chlorides $\mathrm{CI}^{-}$that ranged between $0.06-0.84 \%$ with a rate of $0.29 \%$. Finally, the percentage of organic matter (O.M.) ranged between $0.220-0.52 \%$ and a rate of $0.39 \%$.

\section{Evaluations of Laboratory Bricks and Results}

\subsection{Evaluative Checks for Manufactured Bricks}

In all evaluation tests for the produced bricks, Iraqi Standard specifications No. 25 (IQS, 1988) were approved, (Table 8).

\subsection{Physical Properties of Bricks and Results}

\subsubsection{Linear shrinkage and volumetric shrinkage}

The linear and volumetric shrinkage are the amounts of deficiency that occurs in the original length of the sample from the proud brick as a result of burning it, and it is expressed in a percentage, and it can be measured according to the following law:

Linear shrinkage ratio= [(length before burning - length after burning) / length before burning $]$ x 100 
One of the important factors that depend on longitudinal contraction is the size and shape of the grains involved in the manufacture of bricks, as the longitudinal shrinkage increases or reaches $15 \%$ in the clays of soft grains with high plasticity, and is very small in the clay sandy non-plastic (Alabi et al. (2020). The rate of shrinkage of the Montmorillonite metal is twice the proportion Shrinkage of kaolinite, illite and chlorite minerals (Hussin, 2018 and (Awad and Awadh, 2021). As the linear shrinkage rates for the average lengths of ten manufactured samples from each hole ranged between (1.33-4.67) \% and at the rate of (2.89) \%, while the volumetric shrinkage rates ranged between 6.73$8.83 \%$ and at the rate of $8.16 \%$ (Table 9 ).

Table 8. Physical requirements for clay bricks according to Iraqi Standard Specifications No. 25 (IQS, 1988)

\begin{tabular}{cccccc}
\hline Brick Class & $\begin{array}{c}\text { Minimum pressure tolerance } \\
\text { N/ mm2 }\end{array}$ & $\begin{array}{c}\text { The maximum percentage of } \\
\text { water absorption }\end{array}$ & $\begin{array}{c}\text { Efflorescence } \\
\text { (maximum) }\end{array}$ \\
\hline & $\begin{array}{c}\text { The average } \\
\text { pressure } \\
\text { resistance of } \\
\text { ten bricks }\end{array}$ & $\begin{array}{c}\text { The pressure } \\
\text { resistance of } \\
\text { single bricks }\end{array}$ & $\begin{array}{c}\text { The } \\
\text { absorption } \\
\text { rate of ten } \\
\text { bricks }\end{array}$ & $\begin{array}{c}\text { Single block } \\
\text { absorption }\end{array}$ & \\
& 18 & 16 & $20 \%$ & $22 \%$ & Light \\
A & 13 & 11 & $24 \%$ & $26 \%$ & Medium \\
B & 9 & 7 & $26 \%$ & $28 \%$ & high \\
C & 9 & & & \\
\hline
\end{tabular}

Table 9. Results of the longitudinal and volumetric shrinkage test for laboratory samples

\begin{tabular}{lcc}
\hline Sample No. & Linear shrinkage & Volumetric shrinkage \\
\hline Mix-M & 3.08 & 8.83 \\
Mix-S & 4.43 & 7.75 \\
Mix-B & 2.83 & 8.76 \\
Mix-T & 2.33 & 7.85 \\
Mix-K & 1.58 & 8.66 \\
Mix-D & 1.33 & 8.64 \\
Mix-AL & 4.67 & 8.07 \\
Mix-SH & 2.83 & 6.73 \\
\hline
\end{tabular}

\subsubsection{Water absorption}

The absorption of water by the bricks is defined as the percentage of the weight of the water absorbed to the total weight of the sample (the block). It was adopted in this examination the following specification (ASTM C20-00, 2010). Also, the Iraqi Standard specifications No. 25 (IQS, 1988), which took place in the laboratories of the Department of Applied Geology, University of Babylon, (Fig. 10), (Table 10). As shown in the table below, the average rate of water absorption for laboratory block samples for the study area is within the required standard No. 25 (IQS, 1988).

Table 10. Results of a water absorption test for laboratory brick samples.

\begin{tabular}{cc}
\hline Samples No. & Water Absorption \\
\hline Mix-M & 17.9 \\
Mix-S & 19.13 \\
Mix-B & 19.42 \\
Mix-T & 22.21 \\
Mix-K & 19.84 \\
Mix-D & 15 \\
Mix-AL & 21.43 \\
Mix-SH & 24 \\
\hline
\end{tabular}




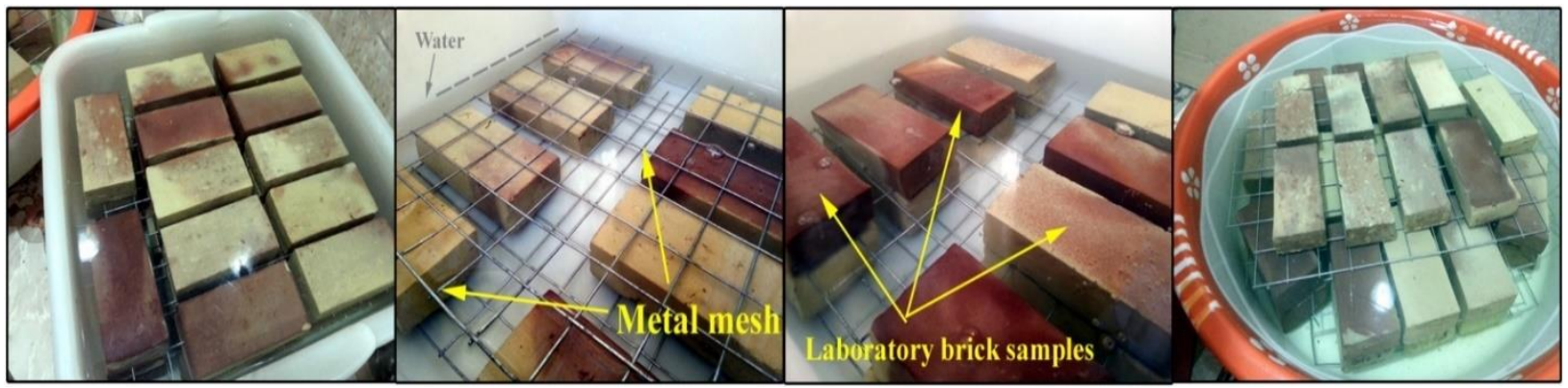

Fig .10. Water absorption test for laboratory samples

\subsubsection{Efflorescence test}

Efflorescence is defined as the phenomenon of crystallization of dissolved salts on the outer surface of the bricks after exposure to water, (Murad, 2017; Awadh and Abdullah, 2011). Efflorescence is of great importance and role in determining the class of bricks according to the Iraqi Standard specifications 25 (IQS,1988), where flowering was examined by placing samples in a container in distilled water to a depth of (1.25) $\mathrm{cm}$ for 10 days and conforming according to the standards as in the (Fig. 11). The efflorescence is varied from the medium, low to nil where the results were respectable for samples manufactured from drilling soils (Mix M, Mix D, Mix K, Mix T, Mix B), the rest of the samples had a poor result within the classification.

\subsubsection{Compressive strength test}

A compressibility strength measurement was performed by using a compressive strength device (Control) with a capacity (from 0 to 3000) kN (Fig. 12). Compression strength is calculated according to the American standard (ASTM C773-88, 2006) as well as according to the Iraqi Standard specifications 25 (IQS,1988), and the results are shown in Table 11 for ten samples from each station.

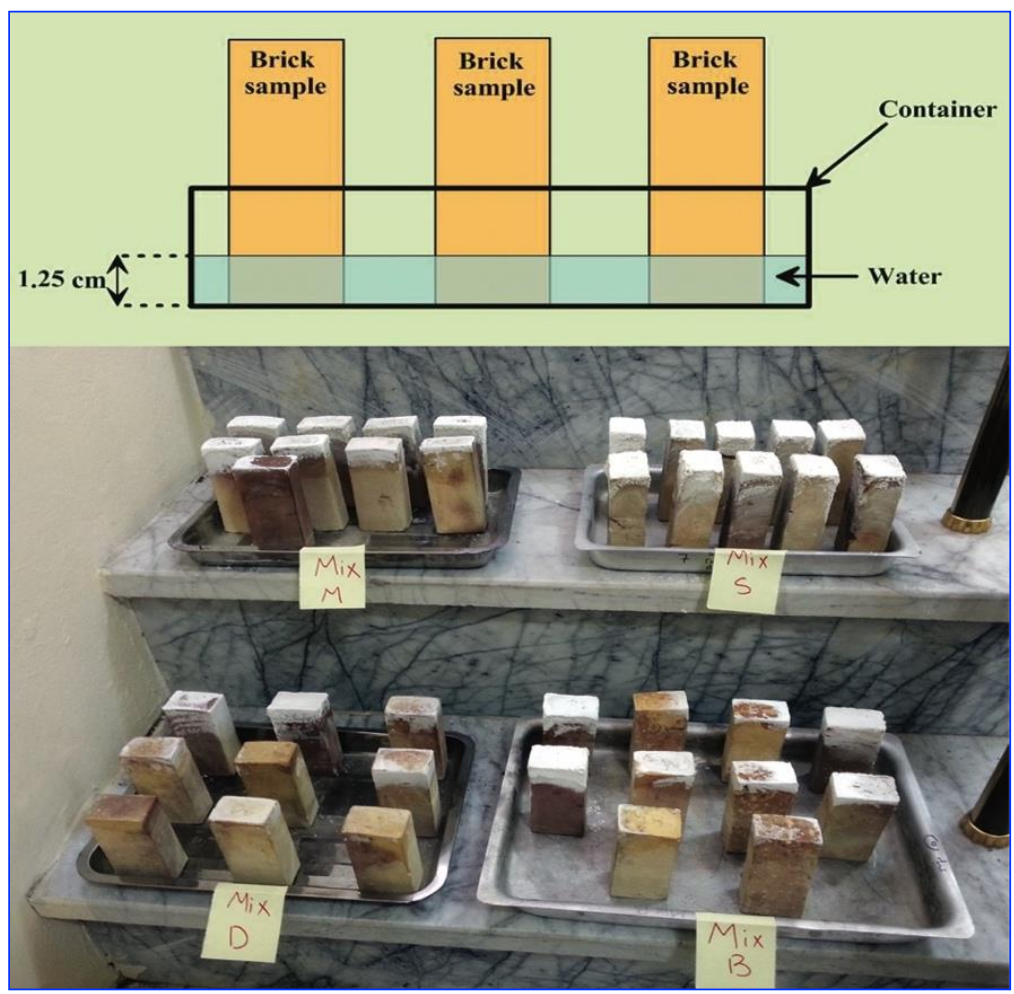

Fig .11. Efflorescence test for laboratory clay brick samples. 
Table 11. Results of compressive strength test of laboratory brick samples

\begin{tabular}{lcc}
\hline Station & Compressive Strength $\left(\mathbf{N} / \mathbf{m m}^{2}\right)$ & Class according $(\mathbf{I Q S}, \mathbf{1 9 8 8})$ \\
\hline Mix-M & 13.13 & $\mathrm{~B}$ \\
Mix-S & 18.19 & $\mathrm{~A}$ \\
Mix-B & 14.21 & $\mathrm{~B}$ \\
Mix-T & 17.83 & $\mathrm{~A}$ \\
Mix-K & 9.86 & $\mathrm{C}$ \\
Mix-D & 7.66 & unconformity \\
Mix-AL & 20.82 & $\mathrm{~A}$ \\
Mix-SH & 9.55 & $\mathrm{C}$ \\
\hline
\end{tabular}

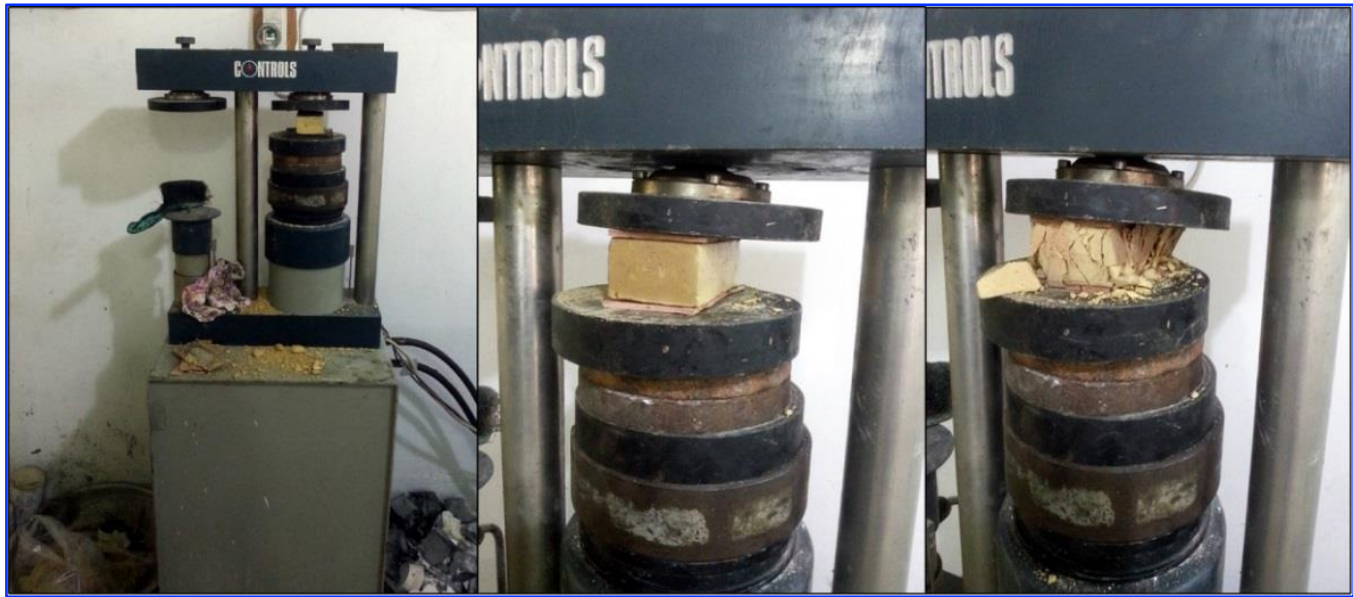

Fig.12. Compressive strength test of laboratory brick samples.

\section{Proposed Proportions for the Manufacture of Clay Bricks}

Through this study, a table was concluded showing the physical and chemical ratios appropriate for manufacturing clay bricks from soils in the sedimentary plain area. Based on this, (Table 12) was proposed.

Table 12. Proposed proportions for the manufacture of clay bricks

\begin{tabular}{ccccc}
\hline Property & Component & Class A & Class B & Class C \\
\hline \multirow{2}{*}{ Grain size } & Sand\% & $12-19$ & $20-24$ & $5-11$ \\
distribution & $\mathrm{Silt} \%$ & $41-47$ & $37-40$ & $41-48$ \\
& $\mathrm{Clay} \%$ & $40-43$ & $40-43$ & $40-47$ \\
& $\mathrm{CaO} \%$ & $11.15-12.22$ & $9-13.5$ & $11.53-13.83$ \\
& $\mathrm{MgO} \%$ & $3.1-3.75$ & $3.41-3.61$ & $3.62-3.81$ \\
Oxides & $\mathrm{SiO}_{2} \%$ & $50-55$ & $53-54$ & $45-56$ \\
& $\mathrm{Fe}_{2} \mathrm{O}_{3} \%$ & $6.1-6.52$ & $6.21-6.34$ & $4.1-5.9$ \\
& $\mathrm{CaCO}_{3} \%$ & $29-33$ & $33-35$ & $35-37$ \\
& $\mathrm{Sulfate} \%^{*}$ Salts & $0.47-1.05$ & $1.41-3.75$ & $2.2-5.41$ \\
& Chlorides\% & $0.061-0.21$ & $0.100-0.34$ & $0.24-0.35$ \\
Plasticity & liquid limit\% & $22-46$ & $24-30$ & $26-28$ \\
& plastic limit\% & $19-25$ & $20-23$ & $22-24$ \\
\hline
\end{tabular}




\section{Conclusions}

The results were obtained from the geotechnical tests (physical, chemical, and engineering tests) For samples extracted from the studied stations. As well as the results of the evaluation tests of the laboratory samples that were made from these soils, it verified that most of the stations are suitable for manufacturing ordinary bricks, except station No.6 (Al-Shenafiya), which needs some additions to be suitable, for examples adding standard sand before soil mix and washing the row materials so carefully. Two classes A and B were obtained through the results of the bricks in most of the stations, except for Station No.5 (Al-Bdair). These came through the match between the laboratory tests and the laboratory samples produced. The study area is suitable with all its stations because they are being far away from the population and being devoid of agriculture (the environmental aspect). Proposal (Table 12), which includes the physical and chemical properties of the manufacture of clay bricks.

\section{Acknowledgements}

The authors would like to thank the Heads of the Department of Applied Geology and the Department of Materials Engineering at the Babylon University for permitting us to use the laboratories and laboratory equipment for physical and Chemical analysis, and thanks to the administration of the Babylon Hawraa Bricks Factory for creating the suitable conditions for burning brick samples. The authors are very grateful to the B. A. CAPTURE group for their great efforts in providing scientific services Such as aerial photos, maps, satellite images, graphics, ideas, and others. The authors are very grateful to the Editor in Chief Prof. Dr. Salih M. Awadh, the Secretary of Journal Mr. Samir R. Hijab. and the Technical Editors for their great efforts and valuable comments.

\section{References}

Ajeet, K. k., 2015. Engineering Materials. Constituent College of Sindh Agriculture University Tandojam, Khairpur College of Agricultural Engineering \& Technology.

Al-Dabbas, M. A., Abbas, M.A., Al-Khafaji, R.M.,2012. Dust storms loads analyses Iraq. Saudi Society for Geosciences, 5,121-131.

Al-Duwaf, Y., 1978. Building Construction and Building Materials. Baghdad: Offset Al-Zaman presses, 393p.

Al-Garawi, Z.F., 2020. Climate and its impact in Some human activities in Babil province. University of Babylon, department of Geography. a master thesis that is not published.

Al-Waeli, M.M., 2018. Basics of Soil Mechanics and its Engineering Applications. Baghdad and Jordan.: Tigris Library, Al-Wadeh Publishing.

Alabi, O.O., Adegun, M., Olatunji, T.,2020. Chemical characterization of Ijapo clay and its additives towards production of refractory bricks. Indian Journal of Engineering. p9.

Awad, A. M., Awadh, S. M., 2020. Reserve estimation of Late Miocene Injana Claystone beds for Portland cement and brick industry, Middle of Iraq. Iraqi Geological Journal, 53, (1D),16.

Awad, A. M., Awadh, S. M.,2021. Manufacturing perforated and ordinary bricks using Injana claystone exposed in The Middle of Iraq. Iraqi Geological Journal., 54 (1A), 11-22.

Awadh, S.M. and Abdullah, H.H., 2011. Mineralogical, geochemical, and geotechnical evaluation of Al-Sowera soil for the building brick industry in Iraq. Arabian Journal of Geosciences, 4(3), 413-419.

Awadh, S.M. and Awad, A.M., 2021. Characterization of Late Miocene Injana claystone from Middle of Iraq for the brick manufacturing. Kuwait Journal of Science, 48(2).

Bapeer, G.B., 2017. Soil behavior and hydrologic properties of Hajiawa area, in sulaymania, Kurdistan, Northeastern Iraq. Iraqi Geological Journal,.50(2), 9.

Camino, M. S., León, F. J., lorent, A., Olivar, J. M., 2014. Evaluation of the behavior of brick tile masonry and mortar due to capillary rise of moisture. University of Valladolid, Spain.

Capture, B. A., 2021. A group that provides scientific services for research such as aerial photographs, digital maps, satellite images, and others through, Babylon Governorates, 
Hawraa, B. P., 2019. The laboratory specification used in the laboratories of Hawraa Babil Bricks Plant, Engineering House Company, Al-Mahaweli, Babylon Governorates, Iraq.

Hussin, A.K., 2018. Mineralogy and geochemistry of clays from Malaysia and its industrial. Malaysia: IOP Conference Series.

Iraqi standard specification, No. 25 of 1988. Iraqi Central Agency for Evaluation and Quality Control. Baghdad.

Iraqi Standard specifications No. 25, 1993. Clay Building Bricks. Baghdad: Central Organization for Standardization and Quality Control.

Khalaf, S.F., 2019. A study of rain and evaporation in Iraq. Associate meteorologist, Iraqi Meteorological Organization and Seismology, 8.

Murad, Z. M., 2017. List of defects in clay bricks. Baghdad, Central Organization for Standardization and Quality Control - Construction Industries Division.

Nesse, W., 2000. Introduction to mineralogy. Britain: Oxford university press, 442 pp.

Norbury, D., 2016. Soil and Rock Description in Engineering Practice. Scotland, UK: Whittles Publishing,321pp. Vodova, L., Sokolar, R., Hroudova, J.,2014. The effect of $\mathrm{CaO}$ addition on mechanical properties of ceramic tiles, International Journal of Civil, Environmental, Structural, 86, 717-720.

Yongue, F., R., Ndimukong, F., Njoya, A.; Kunyukubundo, F., Mbih, P.K., 2016. Mineralogical, geochemical, physical characteristics and properties of their fired products. Journal Asian Ceramic.

Younas, M. J., 2017. Pakistan: University of Engineering \& Technology. 